\title{
ARMIA CZASÓW WOJNY W PROCESIE POLITYCZNYM W ROSJI W 1917 ROKU $^{1}$
}

\section{The war time army in a political process of Russia 1917}

WYRAZY KLUCZOWE: pierwsza wojna światowa, armia rosyjska, rewolucja lutowa, proces polityczny, walka polityczna, rewolucja październikowa

KeYWORDS: First World war, Russian army, February revolution, political process, political struggle, October revolution

Abstract: The article is devoted to the Russian army position in the political process during the revolution of 1917 in Russia. The war period army identity as a social phenomenon, the conditions of its transformation into country political life subject are discussed. The character and the causes of the social political climate of different military men categories on the eve of the revolution are determined. The role of military contingents, institutes, central military figures in the main political events of 1917, such as February and October revolutions, July political crisis, General L. G. Kornilov's march-off is represented. The main regulatory acts of the new government concerning the army, such as Order 1 of Petrograd Soviet of Workers' and Soldiers' Deputies and "Declaration of a Soldier and Citizen Rights", and their influence on the development of the inside situation in the army are considered. The special focus is on the main courses of the army life politization and the political military men's activity, that are the work of army offices, military social organizations, volunteer campaigns in the front line and the back land. The stages and the particular characteristics of the political leaders and military command authority cooperation are specified.

Udział sił zbrojnych Rosji w wydarzeniach rewolucyjnych 1917 r. to zagadnienie, które znajduje się w kręgu zainteresowań rosyjskiej historiografii. Jednakże na przestrzeni prawie stu lat temat ten jako obiekt badań stopniowo ulegał zmianom: od „armii”, rozumianej jako instytucja państwa, charakteryzująca się wewnętrzną funkcjonalną jednością, po „armię” jako specyficzny organizm społeczny, ulegający ewolucji w złożonej sytuacji społeczno-politycznej. We wczesnym okresie badań autorzy mogli jedynie w ogólnym zarysie odtworzyć to zagadnienie pod względem faktologicznym (Деникин 1991; Мартынов 1927). Dla radzieckiej historiografii

${ }^{1}$ Niniejszy tekst został przygotowany w ramach grantu naukowego $\mathrm{nr}$ 19-09-00117A przyznanego przez Rosyjski Fundusz Badań Podstawowych (Российский Фонд Фундаментальных исследований). 
typowe było zainteresowanie udziałem sił zbrojnych oraz przestrzenią walki rewolucyjnej (Муратов 1958; Соболев 1985). We współczesnych badaniach armia rozpatrywana jest nie tylko jako instytucja, lecz także jako społeczność wojskowych, którzy w warunkach kryzysu państwa i społeczeństwa stają się istotnymi aktorami procesu politycznego (Базанов 2003; Назаренко 2011; Тарасов 2017).

W ujęciu politologicznym siły zbrojne państwa zazwyczaj nie są rozpatrywane w charakterze obiektu politycznego, ponieważ pozostając instrumentem władzy, $\mathrm{w}$ istocie nie są reprezentantami samodzielnych interesów politycznych. Jednak kryzys państwowy w Rosji w 1917 r. obnażył niezdolność tradycyjnych instytucji politycznych do pełnienia swojej misji i wprowadził na arenę walki politycznej nowych uczestników. Jednym $\mathrm{z}$ nich stała się armia czasu wojny, powstała w rezultacie masowej mobilizacji i różniąca się od przedwojennej składem kadrowym, strukturą oraz znaczeniem w życiu państwa. Jej jakość i potencjał warunkował poziom kultury i wykształcenia najliczniejszych grup ludności, tj. chłopów i robotników. W związku z tym warto zauważyć, iż w przededniu wojny z obawą odnoszono się do perspektywy powszechnej mobilizacji - „zbrojenia narodu”. W 1910 r. książę W. S. Koczubej na łamach swojej książki poświęconej problemom obrony narodowej odnotował, że w warunkach wielkiej wojny rosyjska ludność pozostanie obojętna wobec wyniku walki zbrojnej Rosji z wrogiem, ponieważ większość narodu pozostaje historycznie wyobcowana od interesów państwa w sferze polityki zagranicznej (Кочубей 1910, 283-284).

W trakcie kilku lat trwania wojny światowej do armii i floty zostało powołanych około 14 mln mężczyzn, przeważnie w wieku 20-40 lat, tj. najbardziej produktywnych z punktu widzenia aktywności zawodowej i społecznej. Z początkiem rewolucji około 6,5 mln ludzi znajdowało się w szeregach armii na froncie i nie mniej niż $2,5 \mathrm{mln}$ przygotowywało się na tyłach (Головин 2001, 170-174). Społeczny wizerunek żołnierzy i marynarzy był odmienny od tego sprzed wojny i w ponad $80 \%$ reprezentowany przez ludność pochodzenia chłopskiego. Wzrost liczebności kadry oficerskiej wywołał zauważalną jej demokratyzację, która jednak objęła jedynie młodszy korpus oficerski (Гребенкин 2015, 98-101).

W wyższych kręgach wojskowych najwyższy status zachowali przedstawiciele poprzedniej elity wojskowo-państwowej, której wpływ i udział w życiu politycznym kraju znacząco wzrosły. Ogromna władza i ważna rola w systemie zarządzania państwem należały do Generalnego Sztabu armii rosyjskiej i wyłonionego z niego Sztabu Naczelnego Dowódcy, utworzonego w celu sprawnego dowodzenia walczącymi wojskami. Z początkiem rewolucji lutowej najwyższe dowództwo wojskowe zostało wciągnięte w rywalizację różnych sił i grup politycznych. Dlatego też nie było już ostoją dla władzy w przypadku niepokojów wewnętrznych.

$\mathrm{Na}$ początku 1917 r. stan i nastroje armii rosyjskiej zasadniczo odpowiadały stosunkowi do wojny, który panował w społeczeństwie, a mianowicie narastającego niezadowolenia z powodu toczących się działań wojennych i rządzenia krajem. 
Już wydarzenia lutowo-marcowe ujawniły zauważalną, a w niektórych przypadkach decydującą rolę wojsk i dowództwa wojskowego w przewrocie politycznym. O ile armia czynna, pozostająca $z$ dala od głównych centrów politycznych, stanęła przed faktem dokonanych przemian, o tyle jednostki tyłowe frontu, przede wszystkim rozmieszczone w wielkich miastach, a zwłaszcza w stolicy, były ich aktywnymi uczestnikami. Nastroje kontyngentu żołnierskiego jednostek rezerwowych, składające się zarówno z rezerwistów, jak i rannych żołnierzy frontowych, którzy powrócili w szeregi armii po rekonwalescencji, były dalekie od wojennego entuzjazmu, a prowadzona wśród nich przez organizacje rewolucyjne agitacja polityczna znajdowała oddźwięk zwłaszcza w związku z jej antywojennym przesłaniem. Jak zaświadczają świadkowie, nawet w stolicy bataliony rezerwowe nie mogły być uznane za pełnowartościowe jednostki wojskowe i stanowiły „zastępy”, grożące wybuchem; był to „materiał ludzki” stanowiący produkt przedłużającej się wojny ${ }^{2}$.

W przededniu wydarzeń rewolucyjnych w Piotrogrodzie władze uznawały wojska garnizonu stołecznego za swoją główną opozycję w walce z zamieszkami. Przy czym o ich „niezawodności” było wiadomo zarówno resortowi obronnemu, jak i dowództwu, ale ani jedni, ani drudzy, jak się wydaje, nie ocenili właściwie grożącego niebezpieczeństwa (Глобачев 2009, 115). Potwierdziły to pierwsze dni powstania w Piotrogrodzie, kiedy nie tylko żołnierze, lecz także i Kozacy nader niechętnie wykonywali rozkazy stłumienia masowych mityngów i demonstracji. Przełomowym punktem całej rewolucji lutowej stał się bunt jednostek garnizonu, rozpoczęty rankiem 27 lutego, który przyczynił się do ostatecznego sukcesu przewrotu w stolicy. Jego triumf uosabiał marsz 28 lutego - 1 marca jednostek wojskowych w kierunku Pałacu Taurydzkiego, gdy kolumny złożone z żołnierzy, dowodzone przez oficerów, przesuwały się w pełnym szyku, z orkiestrą, ozdobione symboliką rewolucyjną. Od tego momentu przedstawiciele wojska i instytucji wojskowych Piotrogrodu brali aktywny udział w działaniach organów dowodzących powstaniem. W skład sztabu rewolucyjnego, działającego przy Tymczasowym Komitecie Wykonawczym Rady Piotrogrodzkiej Delegatów Robotniczych, weszli delegaci zbuntowanych pułków, a dopiero co utworzoną Wojskową Komisję Tymczasowego Komitetu Dumy Państwowej utworzyli oficerowie Dowództwa Naczelnego na czele z posłem Dumy - podpułkownikiem Borysem A. Engelhardtem (Мстиславский 1925, 25).

Nie sprawdziły się plany wykorzystania jednostek frontowych w celu wzmocnienia garnizonu stołecznego. „Pewność” wojsk, rozumiana jako podporządkowanie dowódcom i zdyscyplinowanie w warunkach frontowych, nie oznaczała ich gotowości do wypełniania funkcji policyjnych i karnych na tyłach. Jednostki wycofywane $\mathrm{z}$ frontu, które dotarły do przedmieść Piotrogrodu, mając kontakt z ludnością i wojskami garnizonu, bardzo szybko oznajmiły o swojej solidarności

\footnotetext{
${ }^{2}$ Państwowe Archiwum Federacji Rosyjskiej (ГАРФ). Ф. Р-5881. Оп. 1. Д. 528. Л. 11.
} 
ze zbuntowanym narodem (Мартынов 1927, 148). Na rosyjskiej prowincji, gdzie wydarzenia związane z przewrotem nie miały na tyle dramatycznego charakteru jak w dużych centrach, jednostki i instytucje wojskowe były skłonne zająć wyczekującą pozycję. Jednak podporządkowały się Rządowi Tymczasowemu, jak tylko znane były wyniki wewnętrznej konfrontacji w Piotrogrodzie (Бурджалов 1971, 167-192).

Za równie ważną stronę udziału sił zbrojnych w rewolucji lutowej należy uznać decydującą rolę, którą odegrało w przewrocie główne dowództwo armii czynnej. Dowództwo Naczelne armii rosyjskiej w osobie jej najbardziej wpływowego przywódcy - głównodowodzącego generała Michała W. Aleksiejewa odmówiło wspierania monarchii, znajdując zrozumienie ze strony dumskiej opozycji i zaprezentowało się jako samodzielna siła, zdolna prowadzić własną intrygę polityczną. W wyborze politycznym generalicji znalazły wyraz usilnie propagowane przez liberałów nastroje niezadowolenia z rządu, przekonanie o knowaniach „,ciemnych sił" winnych niepowodzenia armii oraz opinia o tym, że przemiany polityczne $\mathrm{w}$ kraju doprowadzą do zwycięstw na froncie. Rozpoczęta w stolicy rewolucja wywoływała u dowództwa wojskowego ogromne zaniepokojenie, ponieważ była zagrożeniem dla wojennego sukcesu. W celu jej przerwania albo raczej wzięcia pod kontrolę M. W. Aleksiejew i jego podwładni wystąpili jako organizatorzy abdykacji Mikołaja II, której zleceniodawcami byli przywódcy dumskiej opozycji.

Nowa władza rosyjska praktycznie w całości odziedziczyła poprzednie siły zbrojne i system dowodzenia ze wszystkimi charakterystycznymi cechami, problemami i wadami. Wizerunek rosyjskiej armii i marynarki wojennej w kontekście procesu politycznego 1917 r. ukrywa pewne stereotypy, które utrudniają określenie jej prawdziwej roli w wydarzeniach rewolucyjnych. Ogólnie przyjęty scenariusz opisujący losy armii w rewolucyjnym 1917 r. sprowadza się do równoległych procesów demokratyzacji i polityzacji, będących przyczyną nieuniknionego rozkładu i rozpadu armii jako instytucji państwowej i trwałej struktury społecznej. Fenomen ten zasługuje na uwagę, ponieważ w historiografii rozpowszechnione jest wyobrażenie o tym, iż armia „zarażona” wirusem rozkładu z zewnątrz w warunkach społeczno-politycznego kryzysu występowała jako pasywny obiekt oddziaływania sił zewnętrznych: Rządu Tymczasowego, organizacji demokratycznych, partii lewicowych podejmujących z własnej woli lub pod przymusem starania ukierunkowane na jej zniszczenie. Poza tym w miesiącach rewolucyjnych armia wystąpiła jako samoistna siła zdolna do wywierania wpływu, a w niektórych przypadkach do kierowania procesami politycznymi na terenie całego kraju.

Za najważniejszy akt prawny, który dał początek demokratyzacji i w konsekwencji spowodował rozkład armii, przyjęto uważać Rozkaz nr 1 Piotrogrodzkiej Rady Robotników i Delegatów Żołnierskich. Rozkaz ten wydany 1 marca 1917 r. był przeznaczony tylko dla garnizonu Piotrogrodu, ale na skutek szerokiego rozpowszechnienia za pośrednictwem druku i telegrafu został z entuzjazmem przyjęty przez żołnierzy i szybko zaczął być wprowadzany w życie. Przeszkodzić temu 
nie były w stanie ani rozkazy, ani rozporządzenia dowództwa, ani też kolejny Rozkaz nr 2 i wezwanie Komitetu Wykonawczego Rady Piotrogrodzkiej, wyjaśniające ograniczony charakter Rozkazu nr 1. Aleksander I. Denikin, który oczywiście nie był zwolennikiem Rady, przyznał potem, że sukces Rozkazu nr 1 wiązał się z tym, że jego zapisy odpowiadały oczekiwaniom w szeregach żołnierskich na przemiany w wojsku (Деникин 1991, 138). Zgodnie z szeroko rozpowszechnionym przekonaniem przedstawicieli dowództwa wszystkich szczebli Rozkaz nr 1 dał początek rozpadowi dyscypliny w armii i konfrontacji między masą żołnierską i oficerami. Typowa pozostaje opinia A. S. Łukomskiego twierdzącego, że rozkaz „od podstaw naruszał dyscyplinę, pozbawiając kadrę oficerską jakiejkolwiek władzy nad żołnierzami” (Из воспоминаний генерала Лукомского... 1921, 30).

Niemniej jednak przewrót polityczny i pierwsze kroki demokratyzacji armii $\mathrm{w}$ istocie nie stanowiły bezpośredniej przyczyny kojarzonego zwykle $\mathrm{z}$ nimi upadku dyscypliny i rozkładu, których oznaki były zauważalne w wojsku już w latach poprzedzających działania wojenne. Z początkiem rewolucji zaostrzyły się i przyjęły bardziej jaskrawe formy konflikty społeczne, w tym i te, które w armii znajdowały wyraz w rosnącej izolacji mas żołnierskich od oficerów. Rozkaz nr 1 wzywał do ścisłego przestrzegania dyscypliny podczas wypełniania obowiązków służbowych. Upadek autorytetu dowództwa można było upatrywać w pojawieniu się komitetów żołnierskich - formy kontroli społecznej i politycznej w armii, naruszającej pełnię władzy korpusu oficerskiego. Protesty żołnierskie w okresie wcześniejszym w zasadzie miały charakter spontaniczny, zaś z powstaniem komitetów przybrały cechy zorganizowanego protestu politycznego i już nie mogły być stłumione przy zastosowaniu czysto dyscyplinarnych środków opartych na regulaminach wojskowych. Walka o przewagę w komitetach wojskowych i organach przedstawicielskich, a także walka o interesy różnych grup i nurtów w środowisku armii stała się głównym kierunkiem aktywności politycznej żołnierzy w 1917 r.

O ile wsparcie rewolucji przez żołnierzy uwarunkowane było ich wyobrażeniami o sprawiedliwości i zmianach demokratycznych oraz z oczekiwaniem szybkiego pokoju, o tyle reakcja kadry oficerskiej odzwierciedliła jej wewnętrzną niejednorodność, która stała się przyczyną przyszłego rozłamu. Upolitycznienie armii w warunkach rozwoju procesu rewolucyjnego w 1917 r. zazwyczaj wiąże się z zachowaniem żołnierzy. Jednak od pierwszych dni rewolucji działania na rzecz samoorganizacji podejmowała także najbardziej energiczna część generalicji i oficerów. Za jedną z inicjatyw tego rodzaju należy uznać utworzenie w Piotrogrodzie na początku marca $1917 \mathrm{r}$. Rady Delegatów Oficerskich, politycznie zorientowanej na współpracę z Rządem Tymczasowym i z rewolucyjną Radą Delegatów Robotniczych i Żołnierskich. W dalszej kolejności także i w innych garnizonach i jednostkach frontowych powstały Rady Delegatów Oficerskich. Ich utworzenie i działalność, głównie w Piotrogrodzie, oraz lokalnie w innych miejscowościach odbywała się bez sankcji oraz udziału wyższego dowództwa armii, co wywoływało rosnącą irytację z jego strony. 
Szczególnie wrogi stosunek generalicji do tych inicjatyw był spowodowany współpracą Rady Delegatów Oficerskich z Radami Delegatów Robotniczych i Żołnierskich, udziałem w przygotowaniu „Deklaracji praw żołnierza i obywatela” oraz pracy w komisji do spraw reformowania armii generała Aleksieja A. Poliwanowa. W związku z tym oficerowie Naczelnego Dowództwa byli zdania, iż konieczne jest utworzenie „swojej” organizacji oficerskiej, której działalność podlegałaby kontroli dowództwa. Taką właśnie organizacją stał się utworzony przy Naczelnym Dowództwie - Związek Oficerów Armii i Floty, głoszący wśród swoich założeń programowych wszechstronne wsparcie na rzecz przywrócenia dyscypliny i zdolności bojowej wojsk w celu doprowadzenia wojny do zwycięskiego zakończenia. Utworzenie Związku odzwierciedlało również niezadowolenie wyższych kręgów wojskowych z powodu polityki rządu wobec armii. O ile początkowo podstawową formę aktywności Związku stanowiła praca propagandowa, o tyle w czerwcu-sierpniu 1917 r. jego dowódcy nawiązali kontakty konspiracyjne z innymi organizacjami wojskowymi i tą częścią dowództwa, która brała udział w przygotowaniu wystąpienia generała Ławra G. Korniłowa (Кожевин 2005, 139-142).

Rozpowszechnionym zjawiskiem w życiu politycznym kraju wiosną-latem $1917 \mathrm{r}$. był udział przedstawicieli kadry oficerskiej w tworzeniu i działalności licznych organizacji wojskowo-społecznych, które za główny cel swojej działalności ogłosiły wspieranie w armii i społeczeństwie żołnierskiego ducha i tradycji. Wreszcie za charakterystyczne dla tego okresu należy uznać powstanie w środowisku wojskowym organizacji i kółek, mających charakter czysto konspiracyjny i utworzonych jedynie w celu ich wykorzystania dla wprowadzenia dyktatury wojskowej. Jedna z pierwszych organizacji tego typu została utworzona na froncie południowo-zachodnim przez generała Aleksandra M. Krymowa. Inny przykład takiej działalności odnosi się do wiosny 1917 r., kiedy w Piotrogrodzie generał brygady Piotr N. Wrangel i pułkownik Aleksiej P. Pahlen utworzyli tajną organizację wojskową ze swoim sztabem, wywiadem, dobrze zorganizowaną łącznością, opierającą się na młodych oficerach jednostek armijnych i gwardii garnizonu stołecznego. Kontakty konspiracyjne z wojskowymi usilnie nawiązywało „Centrum Republikańskie”, utworzone przez przedstawicieli partii prawicowych i kół przemysłowych. Jego przywódcy - Konstanty W. Nikołajewski i Piotr N. Finisow - za główny cel swojej organizacji uznali wprowadzenie w Rosji dyktatury wojskowej, na czele której miał stanąć jeden z wpływowych dowódców wojskowych.

Aktywność polityczna wpływowych osób resortu wojskowego niejednokrotnie stanowiła rezultat ich osobistej inicjatywy i indywidualnego wyboru. W warunkach pogłębiającego się kryzysu władzy wielu znanych urzędników związanych z wojskiem i wyższych wojskowych, rozczarowanych działaniami oficjalnej władzy i struktur wojskowych, odwoływało się do działalności konspiracyjnej. Pułkownik Borys A. Engelgardt wspominał jedno ze spotkań z naczelnikiem Sztabu Generalnego - generałem Piotrem I. Awerjanowem, podczas którego ten otwarcie twierdził, 
iż zagrożenie dla władzy i armii pochodzi ze strony wodza bolszewików - Lenina, dlatego uważał za konieczne jego fizycznie usunięcie. „Wyznaczyliśmy za jego głowę 200 tysięcy rubli złotem... Znalazł się nawet chętny - oficer bojowy, eser, ale nie budził zaufania"3.

W walkę polityczną, która owładnęła kraj i armię w 1917 r., wciągnięci zostali nie tylko pojedynczy żołnierze, ich grupy i samodzielne organizacje, lecz także oficjalne struktury wojskowo-administracyjne. W porównaniu z okresem przedrewolucyjnym, w składzie Rządu Tymczasowego Ministerstwo Sprawiedliwości i Wojny zajmowało najbardziej wpływową pozycję, a stanowisko ministra zajmowali znani działacze polityczni, którzy w dużym stopniu określali politykę gabinetu. Zmiana ministrów tego resortu następowała w rezultacie kryzysów politycznych z kwietnia i sierpnia, co podkreśla ich kluczową pozycję w rządzie. W lipcu-sierpniu 1917 r., kiedy stanowisko ministra zajmował szef gabinetu Aleksander F. Kiereński, zostało utworzone stanowisko kierującego Ministerstwem Sprawiedliwości i Wojny. Objął je znany działacz partii eserów - Borys W. Sawinkow, który odegrał wiodącą rolę w organizowaniu współpracy kierownictwa politycznego z naczelnym dowódcą wojsk rosyjskich. To minister mianował wówczas głównodowodzącego. Każdy głównodowodzący 1917 r. był wykreowany przez odpowiedniego szefa Ministerstwa Sprawiedliwości i Wojny. Zatem nominacja Michała B. Aleksiejewa nastąpiła jedynie dzięki wpływom Aleksandra I. Guczkowa, kandydatury Aleksieja A. Brusiłowa i Ławra G. Korniłowa stanowiły wybór A. F. Kiereńskiego i odpowiadały jego zamysłom politycznym, jedynie Aleksander I. Wierchowski nie miał możliwości mianować „swojego” głównodowodzącego, ponieważ to stanowisko zajmował A. F. Kiereński, jednocześnie pełniący obowiązki ministra.

Zasadniczo nowym zjawiskiem w całej rosyjskiej armii stało się formowanie aparatu politycznego Ministerstwa Sprawiedliwości i Wojny. Pierwszym krokiem ku temu było powołanie w strukturze ministerstwa Komisji „w celu zmiany aktów prawnych i statutów zgodnie z nowymi normami prawa pod przewodnictwem generała A. A. Poliwanowa”. Do jej zadań należało odnowienie składu armii, opracowanie deklaracji o prawach obywatelskich żołnierzy, wypracowanie propozycji, mających na celu poprawę ich sytuacji służbowej i materialnej, zmianę trybu nagradzania żołnierzy i oficerów oraz o określenie uprawnień komitetów wojskowych w armii. Rezultatem pracy komisji Poliwanowa była „Deklaracja praw żołnierza i obywatela”, określająca wzajemne relacje wojskowych w nowych warunkach. „Deklaracja...”, przygotowana wspólnie z sekcją wojskową Komitetu Wykonawczego Rady Piotrogrodzkiej, stanowiła rezultat kompromisu politycznego i zawierała wiele przeciwstawnych zapisów. Z jednej strony wymuszała bezwzględne przestrzeganie dyscypliny wojskowej, dopuszczała użycie broni przez oficerów, odrzucała zasadę

${ }^{3}$ Naukowo-badawczy dział rękopisów Rosyjskiej Biblioteki Państwowej (НИОР РГБ). Ф. 218. Ед. xp. № 384, c. 43. 
wyborów kadry dowódczej, z drugiej - potwierdzała prawa obywatelskie żołnierzy, w tym prawo członkostwa w dowolnych organizacjach politycznych i społecznych oraz prawo do otwartego wyrażania swoich poglądów, pozwalała na stosowanie kar wyłącznie w trybie służbowym, znosiła obowiązkowe oddawanie honorów wojskowych. Taki dokument nie mógł spełniać oczekiwań najwyższego dowództwa i służyć przywróceniu w armii tradycyjnego ładu. $Z$ tego powodu Denikin obwiniał skład oficerski komisji Poliwanowa o „przestępczy oportunizm” (Деникин 1991, 301). Uświadamiając sobie reakcję Naczelnego Dowództwa, również sam Guczkow odmówił podpisania „Deklaracji...”, co stało się jedną z przyczyn jego dymisji.

Objęcie Ministerstwa Sprawiedliwości i Wojny przez Kiereńskiego przyniosło dwie ważne innowacje o charakterze politycznym. 9 maja 1917 r. Kiereński podpisał dokument „Deklaracja praw żołnierza i obywatela”, co stało się kolejnym krokiem na drodze konfrontacji między władzą a generalicją, broniącą tradycyjnych porządków w armii. W tych dniach Komitet Wykonawczy Piotrogrodzkiej Rady Delegatów Robotniczych i Żołnierskich wyznaczył pierwszych komisarzy wojskowych w sztabach frontu i armii. Od lipca te nominacje i zarządzanie komisarzami rząd realizował na podstawie szeregu regulaminów, przyjętych przez ministra (Солнцева 2002, 86-87). Wprowadzenie podobnego organu kontrolnego $\mathrm{w}$ wojsku nie mogło gwarantować osiągnięcia celów postawionych przed komisarzami - wspierania demokratycznych przemian $\mathrm{w}$ armii. O ile dowódcy widzieli w komisarzach zagrożenie dla swojego autorytetu i wpływów, o tyle dla żołnierzy pozostawali oni przedstawicielami władzy państwowej , opowiadającej się za kontynuowaniem wojny.

Wydarzenia lipcowego kryzysu politycznego skłoniły liderów Rządu Tymczasowego do wzmożenia kampanii propagandowej oraz nasilenia kontroli politycznej $\mathrm{w}$ armii. W tym celu 3 sierpnia, na mocy wspólnego rozkazu Ministerstwa Sprawiedliwości, Ministerstwa Spraw Wojskowych i Marynarki i premiera Kiereńskiego, zostało utworzone Biuro Polityczne Ministerstwa Sprawiedliwości i Ministerstwa Spraw Wojskowych i Marynarki Jako pierwszy obowiązki naczelnika objął porucznik Fiodor A. Stepun, doktor filozofii, bliski eserom. Biuro Polityczne nieprzypadkowo pojawiło się w sierpniu 1917 r., gdyż celem jego powstania było wojskowo-administracyjne i propagandowe wsparcie programu Korniłowa uzdrowienia sytuacji w kraju i armii (Сенин 1995, 145).

Zasadniczym problemem życia politycznego Rosji między lutym i październikiem 1917 r. niewątpliwie pozostawała kwestia kontynuowania wojny. Była ona decydująca dla przyszłej władzy politycznej, w największym stopniu dotyczyła bowiem losu armii i interesów wojskowych. Stosunek do wojny stał się głównym punktem, wokół którego rozwinęła się konfrontacja w środowisku wojskowych. Nastroje mas żołnierskich w znaczącej mierze opierały się na przekonaniu, iż konsekwencją przewrotu rewolucyjnego nieuchronnie stanie się zakończenie wojny. Pod wpływem propagandy partii rewolucyjnych żołnierze uznawali ją za jeden 
Z wytworów poprzedniego, niesprawiedliwego ładu społecznego. Na skutek rosnących antywojennych dążeń żołnierzy i marynarzy następował szybki upadek dyscypliny i zdolności bojowej. Godny uwagi jest fakt, iż najwyższe dowództwo wojskowe skłonne było całkowicie zdjąć z siebie odpowiedzialność za stan wojska, tłumacząc go wyłącznie demokratycznymi zmianami i skutkami antywojennej propagandy. W raportach dowództwa wojskowego składanych rządowi szczególnie koncentrowano się na działalności delegatów partii i organizacji politycznych, prowadzących w armii agitację polityczną i tym sposobem podrywających jej ducha bojowego. Jednocześnie władze nie rezygnowały z prowadzenia agitacji przeciwstawnej, pokazującej korzyści z kontynuowania wojny, która realizowana była przy akceptacji dowództwa. W celu jej organizacji zostały zmobilizowane znaczące siły i środki rządu, partii politycznych i organizacji społecznych, usilnie propagujących rządową linię na rzecz dalszego prowadzenia działań wojennych (Сенин 1990, 213). Mоżna twierdzić, że wiosną i latem 1917 r. armia, zarówno na tyłach, jak i na froncie, stała się areną propagandowego zmagania się partii „wojny” i partii „pokoju”, w których zwycięstwo przypadło tej drugiej, liczniejszej.

Świadkowie tych wydarzeń zwracali uwagę na to, że wybór żołnierzy w tych warunkach nie był polityczny z punktu widzenia formy, tj. nie oznaczał świadomego i konsekwentnego wsparcia tej czy innej opcji partyjnej (Брусилов 2001, 208-209). W rzeczywistości, ze względu na niski poziom piśmienności i tradycyjnej mentalności, chłopi wcieleni do wojska słabo przyjmowali polityczną propagandę dowolnego rodzaju, ale czerpali z niej to, co było dla nich zrozumiałe i odpowiadało ich wyobrażeniom i interesom. Przy tym niezrozumienie i odrzucenie wojny przez żołnierzy było silniejsze niż zarówno patos agitatorski, jak i argumenty dowódców. Ofensywa na froncie południowo-zachodnim zakończyła się katastrofą 16 czerwca 1917 r. pod Tarnopolem przede wszystkim z powodu odmowy żołnierzy udziału $\mathrm{w}$ walce.

Postępujące procesy rozkładu i katastrofalny upadek zdolności bojowej armii doprowadziły przedstawicieli dowództwa i zwolenników podniesienia dyscypliny i ładu do sformułowania idei powołania jednostek specjalnych, opartych na zasadach służby ochotniczej. Autorzy podobnych projektów zakładali, że takie jednostki, wchłaniając tych najbardziej zdolnych i gotowych do walki, będą przykładem dla żołnierzy i zdołają pociągnąć ich za sobą, co miało być szczególnie istotne w związku z przygotowaniami do letniej ofensywy na froncie. Tworzenie jednostek szturmowych i jednostek „śmierci” nabrało latem 1917 r. zauważalny rozmach i przekształciło się ze zjawiska czysto wojskowo-organizacyjnego w zakrojoną na szeroką skalę kampanię polityczną, która objęła nie tylko armię czynną, lecz także tyły frontu, wpływając na dalszy bieg konfliktu w kraju. Zaostrzenie walki politycznej szybko zmieniło poglądy dowództwa i kierownictwa politycznego na cele i perspektywy formacji ochotniczych. O ile początkowo były one rozpatrywane w kontekście wykorzystania na froncie i jednocześnie jako środek oddziaływania 
wychowawczego na pozostałe wojska, o tyle okoliczności ofensywy letniej i następującego po niej kryzysu politycznego zmusiły władze i wojskową górę do ujrzenia w oddziałach szturmowych swojego jedynego zbrojnego oparcia na wypadek wewnętrznej konfrontacji.

Wydarzenia lipcowe w Piotrogrodzie, w których jednostki wojskowe i organizacje skupiające żołnierzy i oficerów stały się aktywnymi uczestnikami po obydwu stronach konfliktu, świadczyły o głębokim rozłamie w armii, odpowiadającym głównym tendencjom życia społeczno-politycznego w Rosji. W tych warunkach przedstawiciele wyższego dowództwa wojskowego gotowi byli wystąpić jako samodzielna siła polityczna, wyrażająca interesy narodowe. Ich pozycja została przedstawiona na zwołanym 16 lipca 1917 r. w Naczelnym Dowództwie zebraniu, które można uznać za epokowe wydarzenie w stosunkach między władzą państwową i dowództwem wojskowym. Centralne miejsce w toku zebrania zajęło wystąpienia generała A. I. Denikina, który zarzucił ministrowi A. F. Kiereńskiemu, a częściowo i dowódcy naczelnemu A. A. Briusiłowowi, niewiedzę i fałszywą ocenę stanu wojsk i zaproponował szereg zmian, które powinny jego zdaniem położyć kres niszczeniu armii. W istocie zakładały one zakaz ingerowania kierownictwa politycznego w sprawy armii i przywrócenie pełni władzy dowódcom. Analogiczną pozycję zajął L. G. Korniłow, nieobecny w Naczelnym Dowództwie, który wysłał w tej sprawie telegram do zebranych (Гребенкин 2015, 341-342). Żądania Denikina i Korniłowa brzmiały jak deklaracja polityczna w imieniu całego dowództwa i oficerów armii rosyjskiej - samodzielnej siły społecznej, której znaczenie i miejsce powinno być uznane przez państwo. Nieprzypadkowo emigracyjny badacz, generał Mikołaj N. Gołowin, odnotowywał, że większość wskazanych zmian mogła być zrealizowana jedynie metodami siłowymi w warunkach dyktatury wojskowej (Головин 1937, 135).

Na lipiec-sierpień 1917 r. przypada okres krótkotrwałego aliansu kierownictwa politycznego i dowództwa wojskowego, bazującego na częściowej zbieżności interesów. Naczelne władze wojskowe w osobie nowego głównodowodzącego Korniłowa i władze polityczne w osobie premiera-ministra Kiereńskiego ruszyły na spotkanie, licząc na opanowanie sytuacji w armii i w kraju. Osiągnięcie tych celów wydawało się możliwe jedynie z zastosowaniem radykalnych metod. Korniłow wystąpił jako inicjator przywrócenia kary śmierci na froncie. Została ona wprowadzona 12 lipca 1917 r., jednak i wcześniej praktykowano rozstrzeliwanie bez sądu dezerterów i naruszających dyscyplinę. Dokonywały tego oddziały karne ochotników-żołnierzy z jednostek szturmowych (Ратьковский 2015, 51-56). W zaistniałej sytuacji podobna polityka „przykręcania śruby” ze strony władzy jedynie prowokowała falę przemocy i nieuchronnie prowadziła do zamiany armii w społeczność dotkniętą nieszczęściem wojny domowej

Projekt wprowadzenia władzy silnej ręki na rzecz kontynuowania wojny nie mógł być przygotowywany otwarcie, dlatego przybrał charakter spisku Rządu Tymczasowego z Naczelnym Dowództwem wojsk rosyjskich. Jednak jego realizacja okazała się 
niemożliwa wobec braku wzajemnego zaufania i poszanowania jego uczestników. Podział między nimi doprowadził do wystąpienia generała Korniłowa przeciwko rządowi i sierpniowego kryzysu politycznego, w którym rola sił zbrojnych była wiodąca i ujawniła nowe możliwości. Po pierwsze, Naczelne Dowództwo wystąpiło ze skrajnie prawych pozycji jako samodzielna strona konfliktu, reprezentująca interesy partii „wojskowej”. Po drugie, ujawnił się brak jedności nawet w wyższych kręgach wojskowych, ponieważ absolutna większość dowódców wojskowych wstrzymała się od aktywnego wsparcia Korniłowa i podporządkowała się rządowi. Wreszcie, ze szczególną ostrością ujawnił się problem „pewności” wojsk, gdyż jednostki, wciągnięte w Korniłowowską awanturę, nie wykazały zdecydowania, aby pójść do końca za swoim dowódcą.

Likwidacja buntu Korniłowa przez rząd z dużym wsparciem sił demokratycznych zauważalnie zmieniła całe polityczne spektrum w Rosji. Usuwając jego prawe skrzydło w osobie zbuntowanych generałów, Kiereński z nowym „republikańskim” rządem automatycznie przesuwał się od centrum w kierunku prawicy, dlatego potrzebował zwłaszcza wsparcia wojskowych. Pozycję wojskowej góry jesienią $1917 \mathrm{r}$. określała nie tyle lojalność wobec rządu Kiereńskiego, ile dążenie do przeciwstawienia się rosnącemu w wojsku wpływowi Rad i bolszewików. Posiadając sankcję rządu, Naczelne Dowództwo przystąpiło do przygotowania nowego kontrrewolucyjnego wystąpienia, znanego w rosyjskiej literaturze historycznej pod nazwą „druga korniłowszczyzna” (Поликарпов 1990, 289-326). We wrześniu-październiku 1917 r. odbywały się zakrojone na szeroką skalę przemieszczenia wojsk z frontów na tyły, w kierunku Piotrogrodu i innych dużych centrów przemysłowych oraz węzłów kolejowych. Te przedsięwzięcia z trwogą odbierane były przez siły lewicowe i demokratyczne, niewątpliwie wpłynęły na decyzję kierownictwa bolszewickiego o przejęciu władzy.

Wydarzeń przewrotu październikowego w Piotrogrodzie nie sposób wyobrazić sobie bez udziału formacji wojskowych. Znacząca część stołecznego garnizonu zachowała neutralność, ale na jego „biegunach” określiły się najbardziej upolitycznione kontyngenty. Żołnierze gwardyjskich pułków rezerwy i marynarze floty bałtyckiej byli główną siłą zbrojną po stronie Komitetu Wojskowo-Rewolucyjnego. Rząd opierał się na junkrach ze szkół wojskowych i jednostek szturmowych, ale oni ani pod względem liczebności, ani możliwości bojowych nie byli w stanie przeciwstawić się siłom przewrotu (Соболев 1985, 244-262). Podobnie, jak to było w lutym, przebieg wydarzeń rozstrzygał się nie w gabinetach władzy i kwaterach sztabów, a na ulicach miast i w okolicach Piotrogrodu dzięki wysiłkowi najbardziej licznych i uzbrojonych uczestników - żołnierzy i marynarzy.

We współczesnej historiografii rosyjskiej powszechnym uznaniem cieszyła się koncepcja „człowieka z bronią” - wojskowego wyemancypowanego od państwa, zastępującego bezsilną lub pozbawioną autorytetu władzę (Булдаков 1997, 373). 
W rzeczywistości jednak „człowiek z bronią” nie był jedynym produktem rozpadu starej armii. Na jej ruinach powstawały nowe zjawiska, struktury, nurty, którym przyszło odegrać swoją rolę w kolejnym etapie walki politycznej.

Wśród licznych historycznych precedensów, w które obfitował rok 1917 w Rosji, za jeden z głównych może zostać zapewne uznany następujący: po raz pierwszy w epoce zmian wywołanych wojną światową większość ludności rosyjskiej uzyskała możliwość wywarcia decydującego wpływu na rozwój sytuacji politycznej i w konsekwencji na wizerunek i losy kraju. Wobec słabości legitymistycznych instytutów demokratycznych i braku tradycji, masy wyrażały swoją wolę poprzez bezpośrednie działanie. W tych warunkach wielomilionowa armia czasu wojny wystąpiła jako najbardziej wpływowe „kolegium wyborców”, które zagłosowało za pokojem i przebudową społeczeństwa.

\section{Bibliografia}

BAZANOv, S. N. (2003), Bor'ba za vlast' v deystvuyushchey rossiyskoy armii (oktyabr' 1917 - fevral' 1918 gg.). Moskva. [Базанов, С. Н. (2003), Борьба за власть в действующей российской армии (октябрь 1917 - февраль 1918 гг.). Москва.]

Buldakov, V. P. (1997), Krasnaya smuta. Priroda i posledstviya revolyutsionnogo nasiliya. Moskva.

[Булдаков, В. П. (1997), Красная смута. Природа и последствия революционного насилия. Москва.]

Burdzhalov, E. N. (1971), Vtoraya russkaya revolyutsiya: Moskva. Front. Periferiya. Moskva. [Бурджалов, Э. Н. (1971), Вторая русская революция: Москва. Фронт. Периферия. Москва.] Golovin, N. N. (1937), Rossiyskaya kontrrevolyutsiya v 1917-1918 godakh. I-V. Prilozheniye k «Illyustrirovannoy Rossii» na 1937 god. Riga. [Головин, Н. Н. (1937), Российская контрреволюция в 1917-1918 годах. I-V. Приложение к «Иллюстрированной России» на 1937 год. Рига.]

Golovin, N. N. (2001), Voyennyye usiliya Rossii v mirovoy voyne. Zhukovskiy/Moskva. [Головин, Н. Н. (2001), Военные усилия России в мировой войне. Жуковский/Москва.]

GREBENKIN, I. N. (2015), Dolg i vybor: Russkiy ofitser v gody mirovoy voyny i revolyutsii. 1914-1918 gg. Moskva. [Гребенкин, И. Н. (2015), Долг и выбор: Русский офицер в годы мировой войны и революции. 1914-1918 гг. Москва.]

Kochubey, V. S. (1910), Vooruzhennaya Rossiya, eye boyevyye osnovy. Paris. [Кочубей, В. С. (1910), Вооруженная Россия, ее боевые основы. Paris.]

Kozhevin, V. L. (2005), Deyatel'nost' Soyuza ofitserov armii i flota (may - avgust 1917 g.). W: Voprosy istorii. 9, 137-142. [Кожевин, В. Л. (2005), Деятельность Союза офицеров армии и флота (май - август 1917 г.). W: Вопросы истории. 9, 137-142.]

MARTYNOv, E. I. (1927), Tsarskaya armiya v Fevral'skom perevorote. Leningrad. [Мартынов, Е. И. (1927), Царская армия в Февральском перевороте. Ленинград.]

Muratov, Кн. I. (1958), Revolyutsionnoye dvizheniye v russkoy armii v 1917. Moskva. [Муратов, Х. И. (1958), Революционное движение в русской армии в 1917. Москва.]

NAZARENKo, K. B. (2011), Flot, revolyutsiya i vlast'v Rossii: 1917-1921. Moskva. [Назаренко, К. Б. (2011), Флот, революция и власть в России: 1917-1921. Москва.]

Polikarpov, V. D. (1990), Voyennaya kontrrevolyutsiya v Rossii. 1905-1917 gg. Moskva. [Поликарпов, В. Д. (1990), Военная контрреволюция в России. 1905-1917 гг. Москва.]

RAT"KovskiY, I. S. (2015), Vosstanovleniye v Rossii smertnoy kazni na fronte letom $1917 \mathrm{~g}$. W: Noveyshaya istoriya Rossii. 1(12), 48-58. [Ратьковский, И. С. (2015), Восстановление в России смертной казни на фронте летом 1917 г. W: Новейшая история России. 1(12), 48-58.] 
Senin, A. S. (1995), Voyennoye ministerstvo Vremennogo pravitel'stva. Moskva. [Сенин, А. C. (1995), Военное министерство Временного правительства. Москва.]

Senin, A. S. (1990), Kornilovskaya al'ternativa. W: Istoriki otvechayut na voprosy. 2. [Сенин, А. C. (1990), Корниловская альтернатива. W: Историки отвечают на вопросы. 2.]

Sobolev, G. L. (1985), Petrogradskiy garnizon v bor'be za pobedu Oktyabrya. Leningrad. [Соболев, Г. Л. (1985), Петроградский гарнизон в борьбе за победу Октября. Ленинград.]

Solntseva, S. A. (2002), Komissary v armii revolyutsionnoy Rossii (fevral' 1917 g. - mart 1918 g.) W: Otechestvennaya istoriya. 3, 83-99. [Солнцева, С. А. (2002), Комиссары в армии революционной России (февраль 1917 г. - март 1918 г.). W: Отечественная история. 3, 83-99.]

TARASOv, K. A. (2017), Soldatskiy bol'shevizm. Voyennaya organizatsiya bol'shevikov i levoradikal'noye dvizheniye v Petrogradskom garnizone (fevral' 1917 - mart 1918 g.). Sankt-Peterburg. [Тарасов, К. А. (2017), Солдатский большевизм. Военная организация большевиков и леворадикальное движение в Петроградском гарнизоне (февраль 1917 - март 1918 г.). Санкт-Петербург.]

\section{Źródła}

Brusilov, А. А. (2001), Moi vospominaniya. Moskva. [Брусилов, А. А. (2001), Мои воспоминания. Москва.]

Denikin, A. I. (1991), Ocherki russkoy smuty. Krusheniye vlasti i armii. Fevral' - sentyabr' 1917 g. Moskva. [Деникин, А. И. (1991), Очерки русской смуты. Крушение власти и армии. Февраль - сентябрь 1917 г. Москва.]

Globachev, K. I. (2009), Pravda o russkoy revolyutsii. Vospominaniya byvshego nachal'nika Petrogradskogo okhrannogo otdeleniya. Moskva. [Глобачев, К. И. (2009), Правда о русской революции. Воспоминания бывшего начальника Петроградского охранного отделения. Москва.]

Iz vospominaniy... (1921), Iz vospominaniy generala Lukomskogo. W: Arkhiv russkoy revolyutsii. 2. Berlin. [Из воспоминаний генерала Лукомского . W: Архив русской революции. 2. Берлин.]

Mstislavskiy, S. D. (1922), Pyat' dney: Nachalo i konets fevral'skoy revolyutsii. Berlin/Peterburg/ Moskva. [Мстиславский, С. Д. (1922), Пять дней: Начало и конец февральской революции. Берлин/Петербург/Москва.] 
